TARNOWSKIE STUDIA TEOLOGICZNE 37 (2018) NR 1-2, S. 9-30

http://dx.doi.org/10.15633/tst.3249

ks. Robert Groch ${ }^{1}$

UNIWERSYTET PAPIESKI JANA PAWŁA II W KRAKOWIE

\title{
Ks. prof. dr hab. Antoni Żurek - curriculum vitae i dorobek naukowo-dydaktyczny
}

\section{Curriculum vitae}

Ksiądz Antoni Władysław Żurek, syn Władysława i Marii Reczek, urodził się 17 kwietnia 1953 roku w Przyborowie, parafia Szczepanów. Po ukończeniu szkoły podstawowej w Przyborowie, w roku 1968 podjął naukę w Liceum Ogólnokształcącym w Brzesku. W 1972 roku złożył egzamin dojrzałości i wstąpił do Wyższego Seminarium Duchownego w Tarnowie. Dnia 29 maja 1978 roku, po ukończeniu studiów teologicznych w Instytucie Teologicznym w Tarnowie, przyjął święcenia kapłańskie z rąk biskupa tarnowskiego Jerzego Ablewicza.

Po święceniach pełnił obowiązki wikariusza w parafii św. Stanisława Kostki w Tarnowie (1978-1980). W 1980 roku został skierowany na studia specjalistyczne z patrologii do Instytutu Patrystycznego Augustinianum w Rzymie. Studia ukończył 5 czerwca 1985 roku, przedstawiając dysertację na temat: Il matrimonio nei Sermoni di Cesario di Arles. W okresie od 1 czerwca do 30 listopada 1997 roku przebywał w Niemczech jako stypendysta Katolickiego Uniwersytetu w Eichstätt.

Po powrocie ze studiów w Rzymie przez dwa lata (1986-1988) pracował jako wikariusz w parafii św. Mikołaja w Bochni. W 1988 roku objął funkcję prefekta w Wyższym Seminarium Duchownym w Tarnowie, którą sprawował aż do

1 Ks. Robert Groch - prezbiter diecezji tarnowskiej, ukończył studia licencjacjackie w zakresie teologii patrystycznej na Wydziale Teologicznym Sekcja w Tarnowie i w zakresie filologii klasycznej i łaciny chrześcijańskiej w Instytucie „Latinitas” na Uniwersytecie Salezjańskim w Rzymie, prowadzi wykłady z języka łacińskiego i greckiego, ćwiczenia z patrologii na Wydziale Teologicznym Sekcja w Tarnowie Uniwersytetu Papieskiego Jana Pawła II w Krakowie, prefekt Wyższego Seminarium Duchownego w Tarnowie (2006-2018), dyrektor Biblioteki Wyższego Seminarium Duchownego w Tarnowie (od 2014). 
roku 1997. Z chwilą podjęcia posługi przełożonego tarnowskiego seminarium rozpoczął również pracę dydaktyczną w Instytucie Teologicznym w Tarnowie, jako wykładowca języka łacińskiego, patrologii, historii Kościoła w starożytności. W latach 1991-2001 pełnił funkcję dyrektora Biblioteki Wyższego Seminarium Duchownego w Tarnowie.

W wieloletniej pracy dydaktycznej, oprócz wspomnianych już wykładów prowadzonych na Wydziale Teologicznym Sekcja w Tarnowie, ks. prof. Żurek wykładał też patrologię w Wyższym Seminarium Misyjnym Księży Sercanów w Stadnikach (w latach 1990-2013), w Instytucie Teologicznym Księży Misjonarzy w Krakowie (1992-1994), w Wyższym Seminarium Duchownym Zakonu Paulinów w Krakowie na Skałce (1993-1994), w Wyższym Seminarium Duchownym w Rzeszowie (1994-1998) oraz w Wyższym Seminarium Duchownym Redemptorystów w Tuchowie (2000-2001).

W latach 1997-2010 był redaktorem „Tarnowskich Studiów Teologicznych”. Od roku 1992 aż do roku 2007 pełnił funkcję Sekretarza Polskiej Sekcji Patrystycznej.

W roku 2000 został Prodziekanem Wydziału Teologicznego w Tarnowie Papieskiej Akademii Teologicznej w Krakowie. W latach 2004-2010 pełnił funkcję Dziekana Wydziału Teologicznego Pat w Krakowie, później Uniwersytetu Papieskiego Jana Pawła II w Krakowie.

W roku 2001 został adiunktem Papieskiej Akademii Teologicznej w Krakowie, a 1 lutego 2014 roku - profesorem nadzwyczajnym Uniwersytetu Papieskiego Jana Pawła II w Krakowie.

W latach 2005-2010 pełnił funkcję Konsultora Rady Naukowej Konferencji Episkopatu Polski, a od roku 2007 do 2010 był członkiem Komitetu Nauk Teologicznych przy Polskiej Akademii Nauk. W roku 2016 otrzymał nominację na Konsultora Kongregacji Edukacji Katolickiej. Należy do następujących organizacji naukowych: Sekcji Patrystycznej przy Konferencji Episkopatu Polski, „Association Internationale d'Études Patristiques”, Polskiego Towarzystwa Teologicznego oraz Tarnowskiego Towarzystwa Naukowego, którego zarządu jest członkiem.

Doktorat uzyskał w Instytucie Patrystycznym Augustinianum w roku 1985. Kolokwium habilitacyjne w oparciu o pracę Duszpasterz końca epoki patrystycznej. Tożsamość kapłana $w$ świetle „De vita contemplativa” Juliana Pomeriusza odbyło się 10 czerwca 1998 roku i zakończyło się uzyskaniem tytułu naukowego doktora habilitowanego na Wydziale Teologicznym Papieskiej Akademii Teologicznej w Krakowie. Tytuł profesora nauk teologicznych otrzymał 
19 grudnia 2014 roku na podstawie rozprawy „Mysterium passionis - corpus et sanguis Christi - communio". Eucharystia sakramentem wtajemniczenia chrześcijańskiego $w$ Kościele łacińskim czwartego i początku piątego wieku, która została wydana w Katowicach w 2012 roku.

\section{Dorobek naukowy - publikacje}

\section{Książki}

1. Il matrimonio nei Sermoni di Cesario di Arles, Roma 1985.

2. Wprowadzenie do Ojców Kościoła, Kraków 1993.

3. Duszpasterz końca epoki patrystycznej. Tożsamość kapłana $w$ świetle „De vita contemplativa" Juliana Pomeriusza, Tarnów 1998.

4. Wprowadzenie do Ojców Kościoła, wyd. 2 popr. i uzupełnione, Tarnów 1998.

5. Pierwsze wieki Kościoła (I-VII wiek), Tarnów 2000.

6. Święty Stanisław ze Szczepanowa: Biskup-Męczennik, Szczepanów 2000.

7. Z Maryja uwielbiajmy Boga, Tarnów 2000.

8. Z Chrystusem za przykładem Maryi w nowe tysiąclecie, Tarnów 2001.

9. Cezary z Arles (Wielcy Ludzie Kościoła), Kraków 2003.

10. Pierwsze wieki Kościoła (Academica 42), wyd. 2 popr., Tarnów 2007.

11. Stanisław ze Szczepa.nowa (Wielcy Ludzie Kościoła), Kraków 2007.

12. Święty Bazyli Wielki (Wielcy Ludzie Kościoła), Kraków 2009.

13. „Mysterium passionis - corpus et sanguis Christi - communio”. Eucharystia sakramentem wtajemniczenia chrześcijańskiego w Kościele łacińskim czwartego i początku piątego wieku, Katowice 2012.

14. Ojcowie Kościoła - twórcy i świadkowie Tradycji (Academica 87), Tarnów 2013.

15. Katechumen - chrześcijanin - wierny. Przygotowanie do chrztu i chrzest w Kościele starożytnym ( $\alpha$ - teologia dla wszystkich 12), Tarnów 2017.

\section{Artykuły naukowe}

1. Literacki i teologiczny aspekt hagiografii patrystycznej, „Collegium Polonorum” 7 (1983-1984), s. 140-155.

2. Letica coniugale in Cesario di Arles: rapporti con Agostino e nuovi orientamenti, "Augustinianum” 15 (1985), s. 565-578.

3. „Mysterium dominicae” w Kościele pierwszych wieków, „Collegium Polonorum” 8 (1985-86), s. 81-96. 
4. Liturgia eucharystyczna jako sakramentalne uczestnictwo w liturgii niebiańskiej, w: Pokarm nieśmiertelności, red. W. Myszor, E. Stanula, Katowice 1987, S. 213-220.

5. Małżństwo i prokreacja według Cezarego z Arles, „Vox Patrum” 7 (1987) z. 1213 , s. 427-440.

6. Katecheza Cezarego z Arles, „Vox Patrum” 10 (1990) z. 18, s. 147-156.

7. „Minister Domini”: patrystyczne fundamenty kapłaństwa - św. Ambroży, „Homo Dei” 60 (1991) nr 4 (222), s. 27-34.

8. Obrzęd zawarcia małżeństwa w sztuce starochrześcijańskiej, „Vox Patrum” 11-12 (1991-1992) z. 20-23, s. 139-147.

9. Od Septuaginty do Wulgaty - Biblia w Kościele pierwszych wieków, „Tarnowskie Studia Teologiczne" 11 (1992), s. 99-107.

10. „Misericodia pauperum” w nauczaniu Ojców Kościoła, „Tarnowskie Studia Teologiczne" 12 (1993), s. 211-220.

11. Ewangelizacyjny charakter apologii wczesnochrześcijańskiej?, w: Ewangelizacja w epoce patrystycznej, red. F. Drączkowski, J. Pałucki, Lublin 1994, s. 125-131.

12. La carità cristiana nella Gallia della fine del $v$ e prima metà del vi secolo, w: Cristianesimo e specificità regionali nel Meditarraneo latino (sec. IV-VI) (Studia Ephemeridis Augustinianum 46), Roma 1994, s. 567-572.

13. Rodzina, jakich... mało, „Currenda” 144 (1994) nr 1, s. 108-114.

14. Demokracja i postęp szansą czy zagrożeniem dla „nowej kultury życia”, „Currenda” 145 (1995) nr 4, s. 614-624.

15. Formacja intelektualno-ascetyczna duchowieństwa $w$ v-vi wieku $w$ Galii na podstawie pism św. Cezarego z Arles, „Vox Patrum” 13-15 (1993-1995)

z. 24-29, s. 173-180.

16. New Age - stare poglądy w nowej postaci?, „Religioni et Litteris” 7 (1995), S. $15-19$.

17. „Res Ecclesiae” w Kościele na przełomie V-VI wieku. Na przykładzie Galii, „Analecta Cracoviensia” 27 (1995), s. 353-359.

18. Działalność charytatywna Kościoła w Galii V-VI wieku, „Vox Patrum” 16 (1996) z. 30-31, s. 189-196.

19. „Jesteśmy duszą świata” - moralne podstawy samoświadomości chrześcijańskiej w świetle apologii wczesnochrześcijańskiej, w: Godność chrześcijanina w nauczaniu Ojców Kościoła, red. F. Drączkowski, J. Pałucki, Lublin 1996, s. 37-47.

20. Julian Pomeriusz i jego „De vita contemplativa”. Aktualny stan badań, „Tarnowskie Studia Teologiczne" 14 (1995-1996), s. 197-207.

21. Kłopoty św. Augustyna z, Księgą Rodzaju”, „Currenda” 146 (1996) nr 2, s. 265-278. 
22. Najstarsza homilia chrześcijańska, „Currenda” 146 (1996) nr 4, s. 610-615.

23. Kochaj i czyń co chcesz, w: Świat ludzkich uczuć, red. W. Szewczyk, Tarnów 1997, s. 219-228.

24. Monastyczna duchowość duszpasterza końca epoki patrystycznej, „Vox Patrum” 17 (1997) z. 32-33, s. 291-302.

25. Późnopatrystyczne modele doskonałości chrześcijańskiej, w: Droga doskonalenia chrześcijańskiego w epoce patrystycznej, red. F. Drączkowski, J. Pałucki, M. Szram, Lublin 1997, s. 103-114.

26. Studium Ojców Kościoła w formacji intelektualnej kapłana, „Dobry Pasterz” 20 (1997), s. 100-106.

27. Tajemnica wiary, w: W Duchu i Prawdzie, red. M.Zając, C. Noworolnik, Tarnów 1997, s. 135-140.

28. To czyńcie na moja pamiątkę, w: W Duchu i Prawdzie, red. M. Zając, C. Noworolnik, Tarnów 1997, s. 141-145.

29. Duch Święty jako Dar i Miłość według Augustyna, „Tarnowskie Studia Teologiczne" 17 (1998), s. 36-46.

30. „Ojcowie Kościoła a nauka”, czyli dalszy ciag nieporozumienia, w: Ojcowie Kościoła wobec filozofii i kultury klasycznej, red. F. Drączkowski, J. Pałucki, M. Szram, Lublin 1998, s. 13-24.

31. Święty Augustyn komentuje „Księgę Rodzaju”, w: Początek świata - Biblia a na$u k a$, red. M. Heller, M. Drożdż, Tarnów 1998, s. 101-117.

32. Tajomstvo viery, w: Katechizmus Katolíckiej cerkvi, Bardejov 1998, s. 125-130.

33. Toto robte na moju pamiatku, w: Katechizmus Katolíckiej cerkvi, Bardejov 1998, s. $31-135$.

34. Gdy do Boga zwracamy się „Ojcze”, „Currenda” 149 (1999) nr 1, s. 109-119.

35. Czy można świętować Dzień Pański tak jak pierwsi chrześcijanie, czyli o niedzieli abstrakcyjnie i konkretnie, „Currenda” 149 (1999) nr 2, s. 254-261.

36. „Początkiem grzechu pycha”-geneza grzechu Adama wedtug św. Augustyna, w: Grzech pierworodny, red. H. Pietras (Źródła Myśli Teologicznej 12), Kraków 1999, s. 101-108.

37. Wkład środowiska tarnowskiego w badania nad antykiem chrześcijańskim, „Vox Patrum" 19 (1999) t. 36-37, s. 117-134.

38. Biblijne podstawy nauki św. Augustyna na temat genezy diabła, w: Demonologia w nauce Ojców Kościoła, red. H. Pietras (Źródła Myśli Teologicznej 17), Kraków 2000, s. 91-98.

39. Skąd wziąt się rok 200o?, „Currenda” 150 (2000) nr 4, s. 598-608.

40. Tajemnica wcielenia $w$ galijskiej literaturze $v$ wieku na przykładzie Jana Kasjana, „Vox Patrum” 20 (2000) t. 38-39, s. 267-280. 
41. Od „paterfamilias” do „Pater noster”. Kontekst kulturowy pojęcia Boga jako „naszego Ojca" w literaturze patrystycznej, w: Bóg Ojciec i przełom wieków w myśli patrystycznej (Studia Antiquitatis Christianae 15), Warszawa 2001, s. 18-28.

42. Chrześcijanie a „upadajacy Rzym”, w: Bóg Ojciec i przełom wieków w myśli patrystycznej (Studia Antiquitatis Christianae 15), Warszawa 2001, s. 133-145.

43. Czy teologia obejdzie się bez nauki i kultury? - dylemat widziany z perspektywy Ojców Kościoła, w: Fides quaerens intellectum, red. S. Budzik, M. Heller (Quaestiones ad disputandum 2), Tarnów 2002, s. 27-48.

44. Laikat rzymski w świetle Mów Leona Wielkiego, „Vox Patrum” 22 (2002) t. 42-43, s. 293-302.

45. Prawo duszpasterzy do „życia z ewangelii” $w$ świetle tradycji patrystycznej, „Tarnowskie Studia Teologiczne” 21/1-2 (2002), s. 97-112.

46. Święci synowie świętych matek, w: Drogi katechezy rodzinnej, red. E. Osewska, J. Stala, Poznań 2002, s. 228-239.

47. Wpływ św. Cezarego z Arles (+542/3 r.) na życie i ksztalt miasta Arles, w: Biskup $i$ jego rola $w$ kształtowaniu miasta późnoantycznego, red. B. IwaszkiewiczWronikowska, D. Próchniak (Sympozja kazimierskie poświęcone kulturze świata późnego antyku i wczesnego chrześcijaństwa 3), Lublin 2002, s. 77-87.

48. Święty Stanisław ze Szczepanowa w świetle najstarszych źródeł, w: Święty Stanisław patronem ładu społecznego, red. B. Wójcik (Quaestiones ad disputandum 4), Tarnów 2003, s. 17-28.

49. Kościót w czasach ostatecznych w świetle Objaśnień Apokalipsy Cezarego z Arles (Studia Antiquitatis Christianae 17), Warszawa 2004, s. 167-175.

50. Leoncjusz z Arles, w: Encyklopedia katolicka, t. 10, red. A. Szostek, E. Ziemann i in., Lublin 2004, kol. 794.

51. Leoncjusz z Cezarei Kapadockiej, w: Encyklopedia katolicka, t. 10, red. A. Szostek, E. Ziemann i in., Lublin 2004, kol. 795.

52. Lex Ecclesiae i ius imperiale - chrystianizacja prawa rzymskiego po edykcie mediolańskim (313 rok), w: Lex Tua in corde meo, red. S. Koperek, J. D. Szczurek, Z. Kijas, S. Szczura, Kraków 2004, s. 585-596.

53. Relacje patriarchatu antiocheńskiego z papieskim Rzymem, „Vox Patrum” 24 (2004) t. 46-47, s. 131-145.

54. W szkole biblijnej św. Hieronima, „Tarnowskie Studia Teologiczne” 23 (2004), s. $101-116$.

55. Dei consul - Boży konsul, „Teologia Patrystyczna” 2 (2005), s. 13-31.

56. Eucharystia - ofiara Nowego Przymierza, według Ojców Kościoła, „Currenda” 155 (2005) nr 1, s. 63-71. 
57. Katechumenat i chrzest w Kościele starożytnym - na przykładzie Antiochii w IV wieku, w: Ku liturgii nadziei, red. R. Biel, Tarnów 2005, s. 117-128.

58. „Pokarm zwany Eucharystia” - w świetle wczesnochrześsijańskich świadectw, "Currenda” 155 (2005) nr 2, s. 241-248.

59. Wczesnochrześcijańska pobożność eucharystyczna, „Currenda” 155 (2005) nr 3, s. 331-339.

60. Chrzest a zbawienie człowieka: ważność i konieczność chrztu w świetle polemiki Augustyna $z$ donatystami, „Vox Patrum” 26 (2006) t. 49, s. 755-766.

61. Co można wyczytać w gwiazdach? - zdaniem Ojców Kościoła, „Tarnowskie Studia Teologiczne" 25/2 (2006), s. 91-100.

62. Człowiek szuka Boga - religijność według św. Augustyna, w: Człowiek i jego religijność, red. A. Żurek (Quaestiones ad disputandum 7), Tarnów 2006, s. 129-148. 63. „Ujrzałem Ducha, który zstępował z nieba jakby gołębica” (J 1,32) - w świetle tradycji patrystycznej, w: Pan moją moca i pieśniq (Ps 118, 14), red. S. Hałas, P. Włodyga (Studia 15), Kraków 2006, s. 305-319.

64. W poszukiwaniu pokoju serc i Mądrości - św. Augustyn w oczach własnych i współczesnych, w: Święty Augustyn dzisiaj. Colloquium Augustinianum, red. W. Dawidowski, Kraków 2006, s. 9-21.

65. Wstęp, w: Augustyn z Hippony, O chrzcie (Źródła Myśli Teologicznej 38), Kraków 2006, s. 5-23.

66. Znaleźć spokój serca - religijność człowieka w świetle „Wyznañ” św. Augustyna, w: Człowiek między losem a wyborem, red. M. Drożdż, Tarnów 2006, s. 323-332. 67. Jan Chryzostom - „biskup jałmużnik”, w: Przebóstwiać to co ludzkie, red. S. Sojka, J. Stala, Tarnów 2007, s. 567-576.

68. Pierwsza Komunia Święta osób dorosłych w praktyce Kościoła pierwszych wieków, w: Eucharystia - pokuta i pojednanie w katechezie. Problemy i wyzwania, red. J. Stala, Kielce 2007, s. 73-82.

69. Bóg miłosierny i do miłosierdzia wzywający według Jana Chryzostoma, „Teologia Patrystyczna" 5 (2008), s. 13-26.

7o. Codzienna Komunia święta w starożytności chrześcijańskiej - aspekt duszpasterski i teologiczny, „Vox Patrum” 28 (2008) t. 52/2, s. 1381-1395.

71. Dramat obcości, w: Zobowiązani do wiary. Po dwudziestu latach na drodze wyznaczonej przez Jana Pawła II (Tarnów, 9-10 VI 1987), red. J. Stala, J. Królikowski, Tarnów 2008, s. 269-274.

72. Mysterium fidei - mysterium tremendum. Transcendentny wymiar ofiary eucharystycznej w literaturze wczesnochrześcijańskiej, w: Męczennicy w świecie późnego antyku, red. B. Iwaszkiewicz-Wronikowska, D. Próchniak (Sympozja 
kazimierskie poświęcone kulturze świata późnego antyku i wczesnego chrześcijaństwa 4), Lublin 2008, s. 157-166.

73. Przygotowanie katechumenów i obrzęd chrztu w świetle katechez Jana Chryzostoma, w: Czasy Jana Chryzostoma i jego pasterska pedagogia, red. N. Widok (Opolska Biblioteka Teologiczna 105), Opole 2008, s. 205-215.

74. „Doctor meus... quem veneror ut patrem”- św. Ambroży w pamięci św. Augustyna, w: Omnia tempus habent, red. A. Reginek, G. Strzelczyk, A. Żądło, Katowice 2009, s. 66-75.

75. Katecheza przedchrzcielna i mistagogiczna w Hipponie w czasach św. Augustyna, „Ruch Biblijny i Liturgiczny” 62 (2009) nr 1, s. 25-36.

76. „Kościót jako nowy Izrael” w świadomości Kościoła starożytnego - na przykładzie Cezarego Arles, „Studia Antiquitatis Christianae” 18 (2009), s. 43-53.

77. Wpływ św. Pawła na nawrócenie Augustyna oraz na jego formację teologiczna, w: Orędzie Pawłowe - aktualne jeszcze dzisiaj?, red. M. Bednarz, P. Łabuda, Tarnów 2009, s. 173-187.

78. Zaślubiny ziemskie i zaślubiny duchowe w tajemnicy chrztu - według Jana Chryzostoma, „Vox Patrum” 29 (2009) t. 53-54, s. 83-93.

79. Diacono defectu presbiteri. Il carattere del servizio del diacono nel V-VI secolo alla luce dei concili della Chiesa latina, w: Diakonia, "diaconiae", diaconato. Semantica e storia nei padri della Chiesa (Studia Ephemeridis Augustinianum 117), Roma 2010, s. 341-350.

80. „Nawróceni chrześcijanie” - duchowość galijskich arystokratów IV-V wieku, „Vox Patrum" 30 (2010) t. 55, s. 809-820.

81. Pamięć zapisana w zwyczaju, w: Pamięć i upamiętnienie w epoce późnego anty$k u$, red. B. Iwaszkiewicz-Wronikowska, D. Próchniak (Sympozja kazimierskie poświęcone kulturze świata późnego antyku i wczesnego chrześcijaństwa 7), Lublin 2010, s. 49-57.

82. Sytuacja prawna laikatu w Kościele pierwszych wieków, w: Lex Tua Veritas. Księga pamiątkowa dedykowana Jego Magnificencji ks. prof. Janowi Maciejowi Dyduchowi z okazji 7o. rocznicy urodzin, red. P. Majer, A. Wójcik, Kraków 2010, s. 361-370.

83. Katechumenat - próba wiary czy charakteru?, w: Katechumenat i inicjacja chrześcijańska w Kościele starożytnym, red. F. Drączkowski, J. Pałucki, Lublin 2011, s. $193-205$.

84. Sacramentum crucis - w duszpasterstwie i teologii ponicejskich Ojców Kościoła, w: Krzyż Twój wielbimy, red. A. Paciorek, A. Tronina, P. Łabuda (Scripturae Lumen 3), Tarnów 2011, s. 393-410. 
85. Starość - sędziwość - dojrzałość. „Senex” i „senectus” w literaturze galijskiej V-VI wieku, „Vox Patrum” 31 (2011) t. 56, s. 393-400.

86. Wydziat Teologiczny Sekcja w Tarnowie w latach 2004-2010, „Currenda” 161 (2011) nr 2, s. 304-310.

87. „Jeden chrzest w jednym i świętym Kościele” - w poszukiwaniu istoty donatyzmu, w: Ortodoksja, herezja, schizma w Kościele starożytnym, red. F. Drączkowski i inni, Lublin 2012, s. 123-132.

88. Katecheza eucharystyczna św. Augustyna, „Vox Patrum” 32 (2012) t. 57, s. $853-862$.

89. Studia o charakterze teologicznym i religijnym $w$ diecezji tarnowskiej od początków jej dziejów. Instytucje, w: Instytucje i wydarzenia, red. A. Gąsior, J. Królikowski (Dzieje Diecezji Tarnowskiej 2), Tarnów 2012, s. 209-226.

90. Dobra doczesne a nadzieja życia wiecznego z perspektywy Ojców Kościoła, „Vox Patrum" 33 (2013) t. 60, s. 535-545.

91. Historia Wydziału Teologicznego w Tarnowie do roku 2010, w: „Tarnowskie Studia Historyczne" 3 (2013), s. 104-120.

92. Specyfika Wydziału Teologicznego Sekcja w Tarnowie, w: Memoriae Ecclesiae custos, red. A. Żurek, J. Jurkiewicz (Dzieje Diecezji Tarnowskiej 3), Tarnów 2013, s. 309-317.

93. „Wierze w Boga Stworzyciela” - geneza i sens formuly, „Tarnowskie Studia Teologiczne" 22/1 (2013), s. 73-84.

94. Chrystianizacja prawa po „Edykcie Mediolańskim”, „Vox Patrum” 34 (2014) t. 61, s. $73-88$.

95.Dziedzictwo porozumienia mediolańskiego z 313 roku, „Currenda” 164 (2014) nr 1, s. 79-85.

96. Biskup w procesie inicjacji chrześcijańskiej w starożytnym Kościele, w: In nomine Domini. Księga pamiątkowa ku czci Księdza Biskupa Jana Styrny w 50. rocznicę posługi kapłańskiej, red. S. Sojka, S. Ewertowski, Olsztyn-Elbląg 2015, s. $65-75$.

97.Bóg Ojciec w tradycji Ojców Kościoła, w: Bóg Ojciec, red. P. Łabuda, Tarnów 2015, s. 159-169.

98.Disciplina arcani $w$ nauczaniu i praktyce duszpasterskiej św. Ambrożego, w: Disciplina arcani $w$ chrześcijaństwie, red. W. Gajewski, B. Górka, Kraków 2015, s. 125-141.

99. Formuly chrystologiczne Symbolu nicejskiego jako element katechezy chrystologicznej IV wieku, w: Jezus Chrystus, red. J. Królikowski, G. M. Baran, P. Łabuda (Scripturae Lumen 7), Tarnów 2015, s. 275-286. 
100. Niebezpieczeństwo arianizmu $w$ świetle „De ratione fidei” Nicetasa $z$ Remezjany, „E-Patrologos” 1/4 (2015), s. 16-26.

101. Troska Kościoła o chrześcijański charakter małżeństwa i rodziny w burzliwych czasach - na przykładzie Galii przełomu v i vi wieku, „Teologia Patrystyczna” 12 (2015), s. 53-67.

102. Wiara według Ojców Kościoła, w: Wierzę, red. P. Łabuda, Tarnów 2015, s. $159-167$.

103. Chrystus - prawdziwy człowiek $w$ wierze Kościoła starożytnego, w: Jezus Chrystus. Świadectwa, red. P. Łabuda, Tarnów 2016, s. 167-178.

104. Chrystus widziany oczami ojców Kościoła, w: Jezus Chrystus. Świadectwa, red. P. Łabuda, Tarnów 2016, s. 179-194.

105. „Człowiek pokoju” (Ps 37, 37) w egzegezie Ojców Kościoła okresu przedkonstantyńskiego, „Verbum Vitae” 30 (2016), s. 13-229.

106. Duch Święty a powołanie do kapłaństwa w Kościele starożytnym, w: Duch Święty, red. J. Królikowski, G. M. Baran, P. Łabuda (Scripturae Lumen 8), Tarnów 2016, s. 257-267.

107. Ewa - pierwsza kobieta w świetle pism świętego Augustyna, „Vox Patrum” 36 (2016) t. 66, s. 139-153.

108. Jezus Chrystus - Syn Boży w wierze starożytnego Kościoła, w: Jezus Chrystus. Świadectwa, red. P. Łabuda, Tarnów 2016, s. 155-166.

109. Motywacje polityczne a religijne $w$ konwersji starożytnych władców, „E-Patrologos” 2/3 (2016), s. 18-29.

110. Patrystyczne „źródła” Jezusa $z$ Nazaretu Josepha Ratzingera Benedykta XVI, w: Jezus z Nazaretu. Poszukiwania chrystologiczne droga wyznaczona przez Josepha Ratzingera - Benedykta XVI, red. J. Królikowski, P. Łabuda, A. Michalik, Tarnów 2016, s. 57-66.

111. Początki hagiografii łacińskiej w świetle najstarszych żywotów biskupich, w: Odpowiednie dać rzeczy słowo..., red. J. Nowak, M. Rzepka, Tarnów 2016, s. 93-102.

112. Dilige et quod vis fac - sens słynnej formuły św. Augustyna, „E-Patrologos” $3 / 3$ (2017), s. 62-69.

113. Duch Święty w świadomości pierwotnego Kościoła, w: Duch Święty, red. P. Łabuda (Źródło Wody Żywej 4), Tarnów 2017, s. 357-369.

114. Duch Święty w Wyznaniu Wiary starożytnego Kościoła, w: Duch Święty, red. P. Łabuda (Źródło Wody Żywej 4), Tarnów 2017, s. 371-383.

115. Inicjacja wczesnochrześcijańska: katechumen - chrześcijanin - wierny, „Studia Theologica Grodnensia" 11 (2017), s. 29-44. 
116. Jak rozumieć znaki zodiaku? - radza Ojcowie Kościoła, w: Niebo. Tradycje, przekazy, inspiracje, red. S. Konarska-Zimnicka, P. Tambora, B. Wojciechowska, Kielce 2017, s. 31-45.

117. Liturgia słowa $w$ świadectwie Ojca Kościoła, w: Liturgia uprzywilejowanym miejscem celebrowania Słowa Bożego, red. W. Pałęcki, A. Megger (Studia Liturgiczne 13), Lublin 2017, s. 11-22.

118. Pneumatologia patrystyczna, w: Duch Święty, red. P. Łabuda (Źródło Wody Żywej 4), Tarnów 2017, s. 385-398.

119. Symbol wiary jako przedmiot „disciplina arcani” $w$ Kościele starożytnym, „Vox Patrum" 37 (2017) t. 67, s. 789-800.1.

120. Bierzmowanie jako sakrament inicjacji w Kościele starożytnym, w: Duch Święty, red. G. Baran, J. Królikowski, P. Łabuda (Scripturae Lumen 10), Tarnów 2018 , s. $367-381$.

121. Obrzęd bierzmowania w nauczaniu św. Augustyna, „Vox Patrum” 38 (2018) t. 69 , s. $771-782$.

122. Synody wczesnochrześcijańskie, w: Synody diecezji tarnowskiej, red. A. Żurek, J. Soprych (Dzieje Diecezji Tarnowskiej 7), Kraków 2018, s. 31-47.

123. Troska Kościoła tarnowskiego o formację intelektualna duchownych. W świetle synodów tarnowskich, red. A. Żurek, J. Soprych (Dzieje Diecezji Tarnowskiej 7), Kraków 2018, s. 153-166.

\section{Recenzje i sprawozdania}

1. Doroczne spotkanie Sekcji Patrystycznej - Nysa 1988, „Vox Patrum” 8 (1988) z. 15, s. 1124-1132, (spraw.).

2. W. Kania, Ojcowie współczesnej wiary. Teksty o Matce Bożej (w. VIII-XI), Niepokalanów 1986, „Homo Dei” 58 (1989) nr 1 (211), s. 76-77, (rec.).

3. G. Dannels, New Age. Nowy ład, nowa ludzkość, nowa wiara, Kraków 1992, ss. 39, „Currenda” 143 (1993) nr 2, s. 296-300, (rec.).

4. L. Gambero, Maria nel pensiero dei padri della Chiesa, ed. Paoline, 1991, ss. 496, „Ateneum Kapłańskie” 85 (1993) t. 120, z. 2, s. 393-394, (rec.).

5. G. Gilson, Les Prêtres. La vie au quotidien, Paris 1990, „Homo Dei” 62 (1993) nr 1 (227), s. 65-67, (rec.).

6. Św. Jan Chryzostom, Dialog. O kapłaństwie, tłum. W. Kania, Kraków 1992, ss. 152, „Homo Dei” 62 (1993) nr 3 (229), s. 102-103, (rec.).

7. La storia della teologia. I. Epoca patristica, a cura di A. Di Berardino, B. Studer, Piemme 1993, ss. 660, „Collectanea Theologica” 64 (1994) z. 4, s. 166-167, (rec.). 
8. J. F. Choroszy, Za i przeciw encyklice „Veritatis Splendor”, Wrocław-Lupstein 1994, ss. 220, „Currenda” 144 (1994) nr 2, s. 310-312, (rec).

9. Nowy obrazśw. Grzegorza z Nyssy w Tarnowie, „Vox Patrum” 13-15 (1993-1995) z. 24-29, s. 683, (spraw.).

10. E. W. Stegmann, Urchristliche Sozialgeschichte. Die Anfänge im Judentum und die Christusgemeinden in der mediterranen Welt, Stuttgart-Berlin-Köln 1997, „Tarnowskie Studia Teologiczne” 16 (1998), s. 156-157, (rec.).

11. J. Kurek, Eucharystia, Biskup i Król. Kult św. Stanisława w Polsce, Wrocław 1998, ss. 400, „Tarnowskie Studia Teologiczne” 17 (1998), s. 135-136, (rec.).

12. W. A. Angenendt, Geschichte der Religiosität im Mittelalter, Darmstadt 1997, ss. 986, „Tarnowskie Studia Teologiczne” 17 (1998), s. 137-139, (rec.).

13. S. Heid, Zölibat in der frühen Kirchen, Padeborn 1997, ss. 339, „Tarnowskie Studia Teologiczne" 17 (1998), s. 139-141, (rec.).

14. Polskie studia nad antykiem chrześcijańskim (Lublin: KUL, 25-26 V 1999), „Vox Patrum" 19 (1999) t. 36-37, s. 687-690, (spraw.).

15. Święta Kinga - patronka Polski i Bochni. Sprawozdanie z sympozjum, „Tarnowskie Studia Teologiczne" 18/2 (1999), s. 163-164.

16. F. Courth, Bóg trójjedynej miłości, Poznań 1997, ss. 327, „Tarnowskie Studia Teologiczne" 18/2 (1999), s. 335-336, (rec.).

17. Millenaryzm wczesnochrześcijański. Sprawozdanie z sympozjum patrystycznego, „Tarnowskie Studia Teologiczne” 19/1 (2000), s. 3-4.

18. Niech ich świadectwo nie będzie zapomniane. Sprawozdanie z sympozjum ku czci bł. Romana Sitki, „Tarnowskie Studia Teologiczne” 19/1 (2000), s. 140-141.

19. Inauguracja roku akademickiego w Tarnowie, „Tarnowskie Studia Teologiczne” 20/2 (2001), s. 143-144, (spraw.).

20. Polska Prymasa Wyszyńskiego, „Tarnowskie Studia Teologiczne” 20/2 (2001), s. $147-148$, (spraw.).

21. Inauguracja roku akademickiego 2002/2003 na WT $w$ Tarnowie, „Tarnowskie Studia Teologiczne" 22/1 (2003) s. 143, (spraw.).

22. Sprawozdanie $z$ działalności $W T w$ Tarnowie $w$ roku akademickim 2001/2002, „Tarnowskie Studia Teologiczne” 22/1 (2003), s. 143-145.

23. Possydiusz z Kalamy, Żywot św. Augustyna, tłum. P. Nehring (Źródła Monastyczne 26), Kraków-Tyniec 2002, ss. 192, „Tarnowskie Studia Teologiczne” 22/2 (2003), s. $159-160$, (rec.).

24. Rocznica kanonizacji św. Stanisława (1253-2003), „Tarnowskie Studia Teologiczne" 23 (2004), s. 383, (spraw.). 
25. Inauguracja roku akademickiego 2004/05, „Tarnowskie Studia Teologiczne” 24/1 (2005), s. 141-142, (spraw.).

26. Sprawozdanie $z$ działalności WT w Tarnowie w roku 2003/o4, „Tarnowskie Studia Teologiczne" 24/1 (2005), s. 142-144.

27. W służbie Bogu, rodzinie, człowiekowi, w: Człowiek między losem a wyborem, red. M. Drożdż, Tarnów 2006, s. 15-16, (rec.).

28. Inauguracja roku akademickiego 2005/o6, „Tarnowskie Studia Teologiczne” 25/1 (2006), s. 128-129, (spraw.).

29. Sprawozdanie z działalności WT w Tarnowie w roku 2004/05, „Tarnowskie Studia Teologiczne" 25/1 (2006), s. 133-136.

30. „Kim jestem - ja człowiek” - sympozjum w 40. rocznicę Konstytucji duszpasterskiej o Kościele, „Tarnowskie Studia Teologiczne” 25/1 (2006), s. 136-137, (spraw.).

31. Inauguracja roku akademickiego 2006/o7, „Tarnowskie Studia Teologiczne” 25/2 (2006), s. 145, (spraw.).

32. Jubileusz 70-tych urodzin ks. prof. dr hab. Michała Hellera, „Tarnowskie Studia Teologiczne" 25/2 (2006), s. 149-150, (spraw.).

33. Pan moja moca i pieśnia (Ps 118,14). Prace dedykowane księdzu profesorowi Tadeuszowi Brzegowemu w 65. rocznicę urodzin, red. S. Hałas scJ, P. Włodyga osB (Studia 15), Kraków 2006, ss. 322, „Tarnowskie Studia Teologiczne” 25/2 (2006), s. 158-159, (rec.).

34. Ku liturgii nadziei. Księdzu dr Bolesławowi Margańskiemu w sześćdziesiąta piątą rocznicę urodzin, red. R. Biel, Tarnów 2005, ss. 500, „Tarnowskie Studia Teologiczne" 25/2 (2006), s. 159 (rec.).

35. Sprawozdanie $z$ działalności WT w Tarnowie w roku 2005/o6, „Tarnowskie Studia Teologiczne" 26/1 (2007), s. 147-149.

36. Misja biskupa w Kościele i społeczeństwie na początku III tysiąclecia. Sesja naukowa w 10. rocznice konsekracji bpa dr W. Skworca, „Tarnowskie Studia Teologiczne" 27/1 (2008), s. 145-146, (spraw.).

37. Roman Brandstaetter - Życie w cieniu krzyża. Sesja popularno-naukowa poświęcona osobie i twórczości R. Brandstaettera, „Tarnowskie Studia Teologiczne” 27/1 (2008), s. 146-147, (spraw.).

38. P. Szczur, Problematyka społeczna w późnoantycznej Antiochii. Na podstawie nauczania homiletycznego Jana Chryzostoma, Lublin 2008, ss. 634, „Tarnowskie Studia Teologiczne" 27/1 (2008), s. 149-150, (rec.).

39. L. Misiarczyk, Osiem logismoi w pismach Ewagriusza z Pontu, Tyniec 2007, ss. 424, „Tarnowskie Studia Teologiczne” 27/1 (2008), s. 160-161, (rec.). 
40. Wizyta kard. Z. Grocholewskiego $w$ wsD i na Wydziale Teologicznym $w$ Tarnowie, „Tarnowskie Studia Teologiczne” 27/2 (2008), s. 153-154, (spraw.).

41. Sprawozdanie z działalności Wydziału Teologicznego za rok 2007/20o8, „Tarnowskie Studia Teologiczne” 28/1 (2009), s. 146-148.

42. Sprawozdanie z działalności Wydziału Teologicznego za rok 200/2009, „Tarnowskie Studia Teologiczne” 28/2 (2009), s. 109-113.

43. G. M. Baran, Motyw „synostwa Bożego” w homiliach Świętego Augustyna do Ewangelii oraz Pierwszego Listu Jana Apostoła, Tarnów 2010, ss. 226, „Tarnowskie Studia Teologiczne” 30/1 (2011), s. 137-138, (rec.).

44. R. Cantalamessa, Sulle spalle dei giganti. Le grandi verità della fede meditate e vissute con i Padri delle Chiesa, Milano 2014, ss. 125, „Tarnowskie Studia Teologiczne" 34 (2015) nr 1, s. 179-181 (rec.).

\section{Publikacje popularno-naukowe, wspomnienia}

1. Studia patrystyczne w Rzymie, „Collegium Polonorum” 8 (1985/86), s. 187-189.

2. Z czego żyje Kościół w Europie?, „Currenda” 144 (1994) nr 2, s. 283-286.

3. Z czego żyje ksiądz w Europie?, „Currenda” 144 (1994) nr 3, s. 457-460.

4. Śp. ks. Bronisław Grzesik, „Currenda” 146 (1996) nr 1, s. 47-48.

5. Ks. W. Mendrala - w 25 rocznicé śmierci, „Currenda” 145 (1995) nr 3, s. 359-365.

6. Czasopisma parafialne - zjawisko kulturowe $i$ problem biblioteczny, w: Problematyka czasopism a funkcje biblioteki akademickiej $w$ procesie naukowo-dydaktycznym, red. W. Bober, Rzeszów 1999, s. 225-228.

7. Ks. Wojciech Kania (1911-200o), „Vox Patrum” 20 (2000) t. 38-39, s. 777-779.

8. Śp. ks. prof. Wojciech Kania, „Currenda” 152 (2002) nr 1, s. 83-91.

9. Ks. prof. dr hab. Jan Dudziak, „Tarnowskie Studia Teologiczne” 21/1-2 (2002), s. 5-9.

10. Laudacja na cześć ks. dr hab. M. Bednarza z okazji wręczenia pamiątkowego tomu TST, „Tarnowskie Studia Teologiczne” 24/1 (2005), s. 145.

11. Wstęp, w: Człowiek i jego religijność, red. A. Żurek (Quaestiones ad disputandum 7), Tarnów 2006, s. 7-11.

12. Geneza i historia powstania Wydziału Teologicznego Sekcja w Tarnowie Papieskiej Akademii Teologicznej w Krakowie, „Tarnowskie Studia Teologiczne” 26/1 (2007), s. 156-159.

13. Słowo Dziekana wTst na św. Szczepana 2008, „Tarnowskie Studia Teologiczne” 28/2 (2009), s. 113-115. 
14. Wstęp, w: Biskupi Tarnowscy okresu komunistycznego: ks. bp Jan Piotr Stepa $i$ ks. abp Jerzy Karol Ablewicz, red. A. Żurek (Quaestiones ad disputandum 10), Tarnów 2010, s. 5-12.

15. Wstęp, w: Odpowiedzialność za życie i stworzony świat, red. A. Żurek (Quaestiones ad disputandum 11), Tarnów 2011, s. 7-8.

16. Apologia to nie tylko odpieranie zarzutów, „Poślij mnie” 20 (2012) nr 4 (96), s. 8-10.

17. Kobieta $w$ starożytności chrześcijańskiej, „Poślij mnie” 24 (2015) nr 4 (108), s. $30-31$.

18. Z wody i Ducha, „Gość Tarnowski” 19.11.2017, nr 46/1259, s. vilI.

\section{Kazania i rozważania}

1. Pojednanie i pokuta, w: Moc i piękno wiary, red. S. Budzik, Tarnów 1995, s. 94-100.

2. Śmierć i życie wieczne w wypowiedziach Ojców Kościoła, w: Kazania pogrzebowe, red. S. Sojka, Tarnów 1995 s. 61-63.

3. Miłość jako dar z siebie w kontekście płciowości, w: $W$ trosce o rodzinę, Tarnów 1996, s. 77-81.

4. Dar mąrości, w: Rozważania na nowennę przed Zesłaniem Ducha Świętego, Tarnów 1998, s. 5-6.

5. Święty Stanisław ze Szczepanowa, w: W liturgii z Maryją wielbimy Boga w Trójcy Świętej. Rozważania majowe, red. S. Sojka, Tarnów 2000, s. 42-43.

6. Z Chrystusem, za przykładem Maryi, w nowe tysiąclecie. Rozważania majowe oparte na liście Jana Pawła II „Novo millennio ineunte”, Tarnów 2001.

7. Stać się - w Nim i przez Niego - dzieckiem Bożym (NMI 23-24), w: Wypłyń na głębię. Wprowadzenie do praktyki chrześcijaństwa $w$ świetle listu apostolskiego Jana Pawła II „Novo millenio ineunte”, red. J. Królikowski, J. Stala, Katowice 2001, s. 74-83.

8. Święci wołaja o świętość, w: Z gwiazda ewangelizacji w trzecie tysiąclecie. Materiały homiletyczne na rok lit. 2000/2001, cz. 4, Tarnów 2001, s. 69-75.

9. Hołd Janowi z Kęt, „Vita Academica” 2006 nr 5-6 (35-36), s. 24.

10. Nasza Droga Krzyżowa, w: Droga krzyżowa, red. J. Bobowski i in., Pleśna 2011, s. 5-9.

\section{Tłumaczenia}

1. List apostolski Duodecimum saeculi, (tł. i oprac.), „Vox Patrum” 10 (1990) z. 19, s. $559-569$. 
2. Encyklika patriarchy konstantynopolitańskiego Dymitriosa I z okazji 1200 rocznicy Soboru Nicejskiego II, (tłum.), „Vox Patrum” 10 (1990) z. 19, s. 570-582.

3. J. Pomeriusz, O życiu kontemplacyjnym, (tłum., wstęp i oprac.), Tyniec 1998.

4. J. Długosz, Święta Matka Kinga. Żywot świętej Kingi według Jana Długosza, (wybór i tłum.), Tarnów 1999.

5. List Apostolski Ojca Świętego Jana Pawła II z okazji 1700 rocznicy chrztu narodu armeńskiego, (tłum.), „Vox Patrum” 21 (2001) t. 40-41, s. 7-15.

6. Homilia Jana Pawła II podczas boskiej liturgii w rycie armeńskim z okazji 1700 rocznicy chrztu narodu armeńskiego w Bazylice Św. Piotra w Rzymie 18 II 2001 roku, (tłum.), „Vox Patrum” 21 (2001) t. 40-41, s. 25-28.

7. Pozdrowienie Nersesa Bedrosa XIX Tarmouni Ormiańskiego Patriarchy Cylicji podczas Boskiej Liturgii $w$ rycie armeńskim $z$ okazji 1700 rocznicy chrztu narodu armeńskiego $w$ Bazylice Św. Piotra w Rzymie 18 II 2001 roku, (tłum.), „Vox Patrum" 21 (2001) t. 40-41, s. 29-30.

8. Cezary z Arles, Homilie do Księgi Rodzaju. Objaśnienie Apokalipsy św. Jana, (wstęp, tłum. i oprac.) (Biblioteka Ojców Kościoła 17), Kraków 2002.

9. Św. Cezary z Arles, (wstęp, oprac. i wybór tekstów) (Ojcowie Żywi 17), Kraków 2002.

10. Augustyn z Hippony, O chrzcie, (tłum., wstęp i oprac.) (Źródła Myśli Teologicznej 38), Kraków 2006.

11. Zenon z Werony, Traktat do nowo ochrzczonych o dwunastu znakach (zodiaku), „Tarnowskie Studia Teologiczne” 25/2 (2006), s. 100-101.

12. Augustyn z Hippony, w: Miłosierdzie. Mądrość Ojców Kościoła, red. D. Trzcinka, Kraków 2015, s. 13-41.

\section{Promotor prac naukowych}

\section{Rozprawy doktorskie}

1. ks. mgr lic. Jerzy Jurkiewicz, Ambrozjańska koncepcja wolności religii chrześcijańskiej - w świetle relacji Ambrożego z Mediolanu z dworem cesarskim, Kraków 2006.

2. ks. mgr lic. Andrzej Romanowski, Droga człowieka do Boga po śladach Mojżesza. Świętość według „Życie Mojżesza” Grzegorza z Nyssy, Tarnów 2018. 


\section{Licencjaty}

1. ks. mgr Jerzy Jurkiewicz, Motyw pokory w "Expositio Evangelii secundum Lucam” św. Ambrożego, Tarnów 1999.

2. ks. mgr Paweł Cyz cor, Specyfika i sens ascezy syryjskich Ojców Pustyni w świetle „Dziejów Miłości Bożej” Teodoreta z Cyru, Tarnów 2002.

3. ks. mgr Krzysztof Mirek, Ojciec Antoni Mieczysław Maria Mirochna - misjonarz w Japonii (1908-1989), Tarnów 2004.

4. ks. mgr Andrzej Romanowski, Teologia i antropologia tekstu o powołaniu Mojżesza (Wj 3, 1-22) w interpretacji Orygenesa, Tarnów 2004.

5. ks. mgr Robert Groch, Zmartwychwstanie ciał w „De civitate Dei”św. Augustyna, Tarnów 2005.

6. ks. mgr Marcin Babiński, Biblia i erystyka w dyspucie teologicznej w świetle „Dziejów procesu Pelagiusza” św. Augustyna, Tarnów 2006.

7. ks. mgr Jacek Zagórowski, Ewangelizacja miejsca biskupa w świetle „Historii Franków" Grzegorza $z$ Tours, Tarnów 2007.

8. ks. mgr Wojciech Witowski, Historia duszpasterstwa w parafii św. Wawrzyńca w Nowym Sączu - Biegonicach. Od powstania do drugiej wojny światowej, Tarnów 2018.

\section{Prace magisterskie}

1. Leszek Durlak, Kapłaństwo w listach Hieronima, Tarnów 1992.

2. Piotr Kisiel, Eschatologia w nauczaniu katechetycznym Augustyna, na podstawie „Podręcznika dla Wawrzyńca czyli o wierze, nadziei i miłości”, Tarnów 1992.

3. Jacek Jackowski, Laikat w Kościele poapostolskim, na podstawie „Didache”, "Listów” św. Ignacego Antiocheńskiego i listu św. Polikarpa, Tarnów 1993.

4. Stanisław Stasiak, Główne tematy mariologiczne w „Protoewangelii Jakuba”, Tarnów 1993.

5. Andrzej Cebulski, Powołanie kapłańskie na podstawie „Księgi reguły duszpasterskiej" Grzegorza Wielkiego, Tarnów 1994.

6. Wacław Paterak, Modlitwa, post i jałmużna a oczyszczenie serca, na podstawie „De Sermone Domini in Monte”'ś. Augustyna, Tarnów 1994.

7. Mariusz Jachymczak, Miłosierdzie u św. Cypriana, Tarnów 1995.

8. Dariusz Konieczny, Małżeństwo i rodzina w świetle apologii wczesnochrześcijańskiej, Rzeszów 1995.

9. Grzegorz Sowa, Gmina chrześcijańska w Kartaginie na podstawie Listów św. Cypriana, Tarnów 1995. 
10. Tomasz Paluch, Teologia i mariologia perykopy o zwiastowaniu w ujęciu Orygenesa, Tarnów 1996.

11. Krzysztof Prokop, Chrystologia i soteriologia Jana Chryzostoma w „Homiliach na listy pasterskie św. Pawła”, Tarnów 1996.

12. Józef Bodziony, Człowiek według traktatu „O zasadach” Orygenesa, Tarnów 1997.

13. Dariusz Mytych, Problematyka małżeńska na synodach w Elwira i Arles, Tarnów 1998.

14. Leokadia Potępa, Maryja w świetle apokryfów o narodzeniu i dzieciństwie, Tarnów 1998.

15. Paweł Cyz, Specyfika i sens ascezy syryjskich Ojców Pustyni w świetle „Dziejów Miłości Bożej” Teodoreta z Cyru, Tarnów 1999.

16. ks. Jerzy Gawle, Św. Aureliusz Augustyn „O kłamstwie”. Wstęp i tłumaczenie, Tarnów 1999.

17. Cyr Mathias Onze, Les problèmes de la Trinité au IV siécle. Controverse de saint Basile et Eunome, Tarnów 1999.

18. Robert Groch, Zmartwychwstanie ciał w „De civitate Dei”św. Augustyna, Tarnów 2000.

19. Edward Kobos, Kościół Oblubienica Chrystusa w komentarzach Orygenesa do „Pieśni nad pieśniami”, Tarnów 2000.

20. Teresa Szumny, Promocja kobiety w apologii wczesnochrześcijańskiej (II-III w.), Tarnów 2000.

21. Joanna Małgorzata Żurek, Wizja kobiety na podstawie „Wyznań”św. Augustyna, Tarnów 2000.

22. Monika Owczarska, Tożsamość chrześcijanina w świetle „Apologetyku”Tertuliana, Tarnów 2001.

23. Renata Stolarczyk, Sny i wizje w najstarszych Męczeństwach. Zasadnicze linie interpretacyjne, Tarnów 2001.

24. Wiesław Jemioło, Chrzest "nowym stworzeniem” i początkiem "nowego życia” w świetle „Katechez chrzcielnych” Jana Chryzostoma, Tarnów 2002.

25. Mieczysław Kita, Ubóstwo i czystość kapłańska w świetle pism św. Jana Chryzostoma na temat kapłaństwa, Tarnów 2002.

26. Stefan Smajdor, Kościót i cesarstwo za czasów Konstantyna W. wobec Ariusza i jego ruchu, w relacji Sokratesa Scholastyka, Tarnów 2002.

27. Marcin Wilczkiewicz, Stosunek św. Augustyna do astrologii i magii w świetle „De civitate Dei”, Tarnów 2002.

28. Marcin Babiński, Biblia i erystyka $w$ dyspucie teologicznej w świetle „Dziejów procesu Pelagiusza"św. Augustyna, Tarnów 2003. 
29. Artur Barszcz, Cesarz Julian Apostata w świetle „Mów” świętego Grzegorza $z$ Nazjanzu, Tarnów 2003.

30. Beata Dynak, Męczennica chrześcijańska w świetle świadectw wczesnochrześcijańskich, Tarnów 2003.

31. ks. Antoni Gieroń, Leon Wielki obrońca jedności Kościoła; w świetle „Mów”, Tarnów 2003.

32. s. Wiesława Longosz, Praca $w$ „Regule Sióstr Służebniczek” w świetle wczesnochrześcijańskich reguł monastycznych, Tarnów 2003.

33. Justyna Marszałek, Dialog chrześcijaństwa z kultura grecka w świetle „Zachęty do Greków" Klemensa Aleksandryjskiego, Tarnów 2003.

34. Barbara Wzorek, Chrześcijański stosunek do własności i majątku w świetle „O Nabocie” św. Ambrożego, Tarnów 2003.

35. Tomasz Szewczyk, Sens ludzkiego życia wświecie według „Homilii na Ewangelie” świętego Grzegorza Wielkiego, Tarnów 2004.

36. Andrzej Śmistek, Postawa człowieka wobec cierpienia w świetle traktatu „O cierpliwości"św. Augustyna, Tarnów 2004.

37. Monika Cichoń, Wspólnotowy charakter Modlitwy Pańskiej w świetle najstarszych komentarzy patrystycznych, Tarnów 2005.

38. Krzysztof Kamieński, Tajemnica Jezusa Chrystusa w świetle traktatu „Podręcznik dla Wawrzyńca czyli o wierze, nadziei i miłości”'św. Augustyna, Tarnów 2005.

39. s. Ewa Pławecka, Teologia cudu w Kanie Galilejskiej w świetle komentarzy do ewangelii Orygenesa i Augustyna, Tarnów 2005.

40. Anna Smoleń, Ideał kobiety chrześcijańskiej na przykładzie Gorgonii, siostry Grzegorza $z$ Nazjanzu, Tarnów 2005.

41. Ewa Bochniak, Rola rodziny w wychowaniu dziecka $w$ świetle dzieła św. Jana Chryzostoma „O wychowaniu dzieci”, Tarnów 2006.

42. ks. Stanisław Oleksyk, Wybrane wątki teologiczne katechezy Cyryllonasa, Tarnów 2006.

43. ks. Marek Szteliga, Wspólnota Ojców Jurajskich i jej duchowość, Tarnów 2006.

44. s. Gabriela Szynol, Pokora i „posłuszeństwo Ewangelii” fundamentem duchowości chrześcijańskiej wświetle, Wielkiego Asketikonu”św. Bazylego Wielkiego, Tarnów 2006.

45. Anna Wolak, Konsolacja chrześcijańska na podstawie listów świętego Hieronima, Tarnów 2006.

46. Krzysztof Romański, „Uczeń Chrystusa” w świetle „Komentarza do Ewangelii według Mateusza" Orygenesa, Tarnów 2007.

47. Łukasz Żurek, Istotne elementy nauki o jałmużnie w świetle „Homilii na Ewangelię według św. Mateusza" św. Jana Chryzostoma, Tarnów 2007. 
48. Łukasz Kulpa, Ofiara Melchizedeka jako zapowiedź ofiary Eucharystii i kaptaństwa Jezusa Chrystusa w świetle wybranych traktatów Ojców Kościoła, Tarnów 2008.

49. Rafał Malec, Małżeństwo chrześcijańskie i ochrona życia na podstawie kanonów synodalnych pierwszych IV wieków, Tarnów 2008.

50. ks. Władysław Mucha, Świętowanie Dnia Pańskiego w pierwszych wiekach Kościoła. Aspekt duszpasterski, Tarnów 2009.

51. Dariusz Bugajski, Cyprian z Kartaginy wobec problemu pokuty i pojednania, Tarnów 2010.

52. Marcin Gryzło, Pokuta w świetle kanonów synodalnych IV wieku, Tarnów 2010.

53. Małgorzata Klimowicz, Wielcy doktorzy Kościoła łacińskiego w sztuce kościołów powiatu tarnowskiego, Tarnów 2010.

54. Katarzyna Kulczyk, Kobieta w świetle komentarzy do Księgi Rodzaju św. Augustyna. Studium antropologii i egzegezy, Tarnów 2010.

55. Jakub Bieszczad, Duszpasterz w świetle „Mów o pasterzach” św. Augustyna, Stadniki 2011.

56. Karolina Dziaduła, Nawrócenie moralne warunkiem chrztu w świetle traktatu św. Augustyna „Wiara i uczynki”, Tarnów 2011.

57. Małgorzta Handzel, Nauka o aniołach w świetle dzieł Orygenesa, Tarnów 2011.

58. Dorota Mitera, Małżeństwo i rodzina w „Homiliach na Ewangelię wedtug świętego Mateusza" Jana Chryzostoma, Tarnów 2011.

59. Tomasz Święs, Tajemnica chrztu w świetle traktatu „O chrzcie” Augustyna $z$ Hippony, Tarnów 2011.

6o. Marcin Łazarz, Elementy antropologii chrześcijańskiej w świetle „Homilii na Ksiege Rodzaju, Rdz 1-3"św. Jana Chryzostoma, Tarnów 2012.

61. Karol Tokarczyk, Droga do świętości, czyli podstawy duchowości Barsanufiusza, Jana i Doroteusza z Gazy, Tarnów 2012.

62. Michał Śliwa, Relacje biskupów z władza świecka w Galii Merowińskiej w świetle "Historii Franków” Grzegorza z Tours, Tarnów 2013.

63. Paweł Wąsik, Relacja Boga do świata w świetle „De gubernatione Dei”Salawiana $z$ Marsylii, Tarnów 2013.

64. Emilia Mrzygłód, Tajemnica Słowa w świetle „Homilii do Ewangelii świętego Jana" św. Augustyna, Tarnów 2014.

65. Tomasz Kaczor, Wartość postu w oparciu o wybrane dzieła św. Bazylego Wielkiego, św. Ambrożego i św. Leona Wielkiego, Tarnów 2015.

66. Paweł Kowal, Dobre wychowanie w świetle pism greckich Ojców Kościoła IV wieku - św. Bazylego Wielkiego i św. Jana Chryzostoma, Tarnów 2015. 
67. Krzysztof Kutek, Ks dr hab. Wojciech Kania. Życie i działalność duszpastersko-dydaktyczno-naukowa, Tarnów 2015.

68. Kamil Olszówka, Postawa biskupa tarnowskiego Jana Stepy wobec ustroju komunistycznego w latach 1946-1959, Tarnów 2015.

69. Antoni Król, Jałmużna w nauczaniu duszpasterskim św. Bazylego Wielkiego, św. Ambrożego i św. Jana Chryzostoma, Tarnów 2016.

70. Mateusz Norek, Ideał duchownego i mnicha w świetle „Dialogów” Grzegorza Wielkiego, Tarnów 2016.

71. Grzegorz Ogórek, „Czcij ojca i matkę swoja” (Wj 20, 12) w tradycji patrystycznej na przykładzie reprezentatywnych pism Ojców Kościoła, Tarnów 2017.

72. Damian Płaza, Epifanie i misja Ducha Świętego w świetle „Homilii na Ewangelię i Pierwszy list św. Jana" świętego Augustyna, Tarnów 2017.

73. Teresa Gofron, Eustochium jako wzór dla dziewic w świetle listów świętego Hieronima, Tarnów 2017.

74. Michał Mos, Rola Konstantyna Wielkiego w rozwoju chrześcijaństwa na podstawie „Historii Kościoła” Sokratesa Scholastyka i „Historii Kościoła” Hermiasza Sozomena, Tarnów 2017.

75. Mateusz Migacz, Posługa biskupa w świetle synodów galijskich w vi vI wieku, Tarnów 2018.

76. Pawlo Tovkach, Eucharystia na podstawie „Canones Patrum Graecorum”, Tarnów 2018.

77. Bartłomiej Wilkosz, Tajemnica chrześcijaństwa według Orygenesa, Tarnów 2018.

\section{Recenzje dorobku naukowego}

\section{Doktoraty}

1. ks. Jerzy Przemysław Duda, Jeden świat czy wiele światów? Kosmologiczne podstawy doktryny Orygenesa, Wydział Teolgii kuL, Lublin 2007.

2. ks. Grzegorz M. Baran, Motyw „synostwa Bożego” w homiliach Świętego Augustyna do Ewangelii oraz Pierwszego Listu Jana Apostoła, Wydział Nauk Humanistycznych Instytut Filologii Klasycznej KUL, Lublin 2010. 


\section{Habilitacje}

1. ks. Stanisław Strękowski, Sofiologia św. Grzegorza z Nyssy. Elementy teologii trynitarnej i antropologii w Homiliach do Pieśni nad pieśniami, Wydział Nauk Historycznych i Społecznych uksw, Warszawa 2007.

2. ks. Piotr Szczur, Problematyka społeczna w późnoantycznej Antiochii. Na podstawie nauczania homiletycznego Jana Chryzostoma, Wydział Teologii KUL, Lublin 2008.

3. ks. Leszek Misiarczyk, Osiem „logismoi” w pismach Ewagriusza z Pontu, Wydział Nauk Historycznych i Społecznych uksw, Warszawa 2008.

4. Rafał Marcin Leszczyński, Starożytna koncepcja Logosu i jej wplyw na myśl chrześcijańską, Снат, Warszawa 2010.

5. ks. Grzegorz Jaśkiewicz, Doketyzm jako wyraz relatywizmu w teologii, Wydział Teologii uksw, Warszawa 2010.

6. ks. Włodzimierz Bielak, Biskup i jego urząd w oczach średniowiecznych kronikarzy polskich, Wydział Teologii KUL, Lublin 2012.

\section{Tytuly profesorskie}

1. ks. dr hab. Józef Grzywaczewski, uksw, Warszawa 2017.

2. dr hab. Krzysztof Leśniewski, KUL, Lublin 2018. 